EISSN: 2706 -7947 ISSN: 2077- 4613

DOI: 10.36632/mejas/2021.11.4.65

Journal homepage: www.curresweb.com

Pages: 849-858

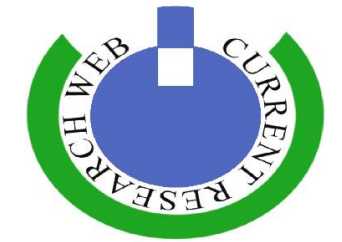

\title{
Economic Study of Foreign Agricultural Trade Flows between Egypt and the COMESA Bloc
}

\author{
Rania M. Barghash and Afaf Z. Othman
}

Department of Agricultural Economics, National Research Centre, 33 El-Buhouth St., Dokki, Cairo, 12622 Egypt

Received: 20 Sept. $2021 \quad$ Accepted: 15 Oct. $2021 \quad$ Published: 30 Oct. 2021

\begin{abstract}
The Common Market for Eastern and Southern Africa (COMESA) is considered of the most important forms of economic cooperation in the African Continent. The research investigates the problem that the volume of trade exchange between Egypt and the COMESA countries in general, and agricultural trade in particular. It only accounts for 7.2\% during (2014-2018) of the volume of trade exchange between Egypt and the world. The research aimed to analyze intra-trade flows between Egypt and countries of the COMESA Bloc over the period (2001-2018) revealed that the value of Egyptian agricultural imports from the COMESA recorded an average of US\$235 million, while the value of Egyptian agricultural exports to the COMESA recorded an average of US\$132 million. Results of estimating the Basic Gravity Model for Egypt's agricultural imports from the COMESA indicated a direct relationship between Egypt's GDP and the volume of Egypt's agricultural imports, where 1\% increase in Egypt's GDP lead to increasing Egypt's agricultural imports by 1.6\%, the existence of common borders between Egypt and the COMESA countries result indicated that it has a direct relationship with the volume of Egypt's agricultural imports from those countries, which is consistent with the economic logic, where the existence of common borders between Egypt and the COMESA countries resulted in increasing Egyptian agricultural imports by 3.22\% .Results of estimating the Basic Gravity Model for agricultural exports indicated that a direct relationship exists between Egypt's GDP and the volume of Egypt's agricultural exports to the six countries, where 1\% increase in Egypt's GDP leads to increasing Egypt's agricultural exports from the six mentioned countries by $0.05 \%$. As for the relationship between the geographical distances between Egypt and each of COMESA countries and Egypt's agricultural exports to those countries, results indicated an inverse relationship, which is consistent with both the economic and statistical logic, where a $1 \%$ increase in the geographical distances resulted in reducing Egypt's agricultural exports to those countries by $0.92 \%$. In regards to the relationship between the dummy variable representing the existence of common borders between Egypt and the COMESA countries, results revealed that it has a direct relationship with the volume of Egypt's agricultural exports to six countries, which is consistent with the economic logic. So the search recommended to: developing the currently existing means of transportation between Egypt and each of the, Studying quality standards requirements of exports demanded by the COMESA markets thus paying attention to improving the quality of Egyptian exports to those markets, Seeking to on open new market windows for Egyptian agricultural exports .
\end{abstract}

Keywords: COMESA, agricultural trade, Gravity Model

\section{Introduction}

The Common Market for Eastern and Southern Africa (COMESA) bloc is one of the most important forms of economic cooperation in the African Continent. The COMESA was formed in 1994 with the membership of 19 countries, these are Egypt, Zambia, Uganda, Malawi, and Eritrea, Burundi, Comoros, Ethiopia, Kenya, Rwanda, Sudan, Swaziland, Zimbabwe, Mauritius, Congo, Seychelles, Djibouti, Madagascar, and Libya. Recently, African countries have tended to adopt economic cooperation rather than political conflict. Therefore, they started concluding trade agreements, 
especially between countries linked to economic blocs. It is worth noting that Egypt has joined a number of world economic blocs. In regards to the COMESA, Egypt has joined the bloc in June 29, 1998, and started implementing the principle of reciprocity through applying tariff exemptions as of February 17, 1999.

Although Egypt was among the first countries to join the bloc, it has not benefited from the bloc so far, where the balance of agricultural trade flow between Egypt and the COMESA countries tends to favor the COMESA countries. Average value of Egyptian agricultural exports to the COMESA countries amounted to U\$162.4 million, representing about 5.8\% of the value of Egypt's agricultural exports to the world during the period (2014-2018), while Egypt's agricultural imports from the COMESA countries reached U\$333 million, representing about $8.2 \%$ of the value of Egypt's agricultural imports from the world. Intra agricultural trade flows between Egypt and the COMESA amounted to some $\$ 495.8$ million, representing about $7.2 \%$ of the volume of agricultural trade flows between Egypt and countries of the world during the period (2014-2018). Despite the agreement between member states of the COMESA bloc to encourage and pump new investments in member countries and establish joint projects, especially in the field of infrastructure, to support investment and increase trade exchange, in addition to strengthening private sector's role in investment flows in member countries in order to promote investment, the volume of investment in member countries is still small compared to other countries.

Among the major advantages of joining the COMESA is allowing Egyptian exports access to a large market with a population estimated at 520 million during the period (2014-2018), complete exemption of Egyptian exports from all custom duties at member states, and benefiting from financial assistance provided by the African Development Bank and other international institutions. Therefore, COMESA markets are considered of the most important markets on which Egypt can rely in increasing exports due to the fact that African markets are considered promising markets, especially in the light of contemporary changes and the currently prevailing unfavorable conditions Egypt's economy face, on top of which is the chronic deficit in the balance of trade. Therefore, joining a strong economic cooperation bloc is a primary goal to improve foreign trade opportunities through increasing the effectiveness of intra-regional trade flows between member countries, and through integration in light of the growingly increasing export competition.

\section{Research Problem}

The research investigates the problem that the volume of trade exchange between Egypt and the COMESA countries in general, and agricultural trade in particular, is considered microcosm and unstable due to being affected by political issues from time to time. It only accounts for $6.5 \%$ of the volume of trade exchange between Egypt and the world. It was found that agricultural trade balance is biased in favor of the COMESA countries. Therefore, Egypt has not benefited so far from the member countries of the bloc. In addition, the volume of investments in both sides is low, whether investments by the COMESA countries inside Egypt, or Egypt's investments inside countries of the bloc.

\section{Research Objectives}

In the light of describing the research problem, the main objective this research aims to achieve is to analyze intra-trade flows between Egypt and countries of the COMESA Bloc, and exploring the ways to achieve full benefit from joining the Bloc.

In order to achieve the research's main objective, it is necessary to first achieve the following subobjectives:

1. Identify foreign trade flows between Egypt and main economic blocs at the level of Africa based on averages of data the period (2014-2018).

2. Conduct a comparison between main economic indicators for the COMESA and Egypt based on averages of data the period (2014-2018).

3. Study the evolution of foreign agricultural trade flows between Egypt and the COMESA Bloc based on averages of data for the period (2014-2018).

4. Analysis of the structure of agricultural exports and imports between Egypt and the COMESA Bloc based on averages of data the period (2014-2018). 
5. Assess the impacts of some international variables like Gross Domestic Product (GDP) for Egypt and the COMESA Bloc and the geographical distance on the volume of the current agricultural trade exchange over the period (2014-2018).

\section{Methodology}

Both descriptive and quantitative economic analyses have been applied to the collected data. The research applied the Gravity Model using cross-sectional and time-series data regression methods to assess trade exchange between Egypt and member countries of the COMESA over the period (20012018). In addition, the research conducted analysis of the cumulative effect to measure the impact of investments on GDP of the COMESA bloc.

In regards to data, the research relied on secondary data published in periodicals and bulletins issued by various institutions on the international information websites (the Internet), including the World Bank, the Central Agency for Public Mobilization and Statistics and the COMESA Organization. In addition, the research relied on some of the research studies, theses, studies and scientific books that dealt with the research subject.

\section{Description of the Applied Model ${ }^{(3)}$}

The Gravity Model is used to estimate agricultural foreign trade flow between Egypt and the COMESA. In 1962, Hogan Tinbergen introduced the gravity model to measure foreign trade. It is similar to Newton's law, which attributes attraction between two bodies to the physical size between their masses and the distance between them. It expresses the economic size of the two countries in terms of GDP, or per capita share of GDP, while expresses the geographic distance between the two countries in thousand kilometers. The Gravity Model will be estimated in two forms:

- Basic Gravity Model (BGM): It reflects the overall impact of each country on Egypt's agricultural exports and imports. Variables employed include GDP for both Egypt and the COMESA countries, in addition to the geographical distance between them. The most important 6 countries that were selected based on absorbed Egyptian agricultural exports include Libya, Sudan, Kenya, Ethiopia, Eritrea, and Djibouti, where the volume of Egyptian exports to the six countries accounts for $96 \%$ of the total volume of Egypt agricultural exports to the COMESA bloc. On the other hand, the most important 6 countries that were selected based on Egyptian agricultural imports include Libya, Sudan, Zambia, Malawi, Ethiopia, and Djibouti, where the volume of Egyptian imports from the six countries accounts for $94 \%$ of the total volume of agricultural imports by Egypt from the COMESA bloc based on averages of data for the period (2001-2018). Two dummy variables have also been used, one to reflect the impact of common borders between the two countries, and the another one to reflect the impact of membership of the Community of Sahel-Saharan States:

\section{$\operatorname{LnY}_{\mathrm{ij}}=\beta 0+\beta 1 \operatorname{lnGDP}+\beta 2 \operatorname{lnGDP} \mathrm{P}_{\mathrm{j}}-\beta 3 \ln \mathrm{Dist}_{\mathrm{ij}}+\beta 4$ Border $D_{\mathrm{ij}}+\beta 5$ Coast, $\operatorname{desertDij}+\mathfrak{f}_{\mathrm{i}}$ Where:}

$\mathbf{Y}_{\mathrm{ij}}$ : Estimated value of Egyptian exports/imports in real prices, to or from country $(\mathrm{j})$ in US\$ million based on price index (base year 1999/2000).

GDP: Real Gross Domestic Product for Egypt (i) in US\$ million.

GDP $_{\mathbf{j}}$ : Real Gross Domestic Product for Egypt (j) in US\$ million.

Dist $_{\mathrm{ij}}$ : Geographical Distance between Egypt and each country (j) in thousand Kilometers.

Border $\mathbf{D}_{\mathrm{ij}}$ : A dummy variable that takes the value 1 in case there is a common border between the two countries $(\mathrm{i}, \mathrm{j})$, and takes the value zero if not.

Coast, Desert $D_{\mathrm{ij}}$ : A dummy variable that takes the value 1 in case the two countries are members of the Community of Sahel-Saharan States, known as the CEN-SAD Community in South African countries. It was established in February 4, 1998, and comprises 29 countries. The dummy variable takes the value zero otherwise.

$\mathfrak{f}_{\mathrm{ij}}$ : Random error of the regression equation 


\section{Results}

\subsection{Foreign Trade Flow between Egypt and Main Economic Blocs in Africa}

Many of the regional blocs are spread throughout the African continent. A phenomenon that is considered of the most important features the world is witnessing in the current era. Such blocs aim to strengthen African relations and activate bilateral trade flows. Some of the blocs aim to attain political and social stability. It is worth noting that some forms of cooperation bring together all of the fifty-four African countries. Therefore, it is important to study the relative importance of total foreign trade between Egypt and economic blocs in the African continent. It is worth mentioning that Egypt is a member of both the COMESA and the Community of Sahel-Saharan States.

Data in Table (1) indicate that foreign trade flow between Egypt and the COMESA Bloc acquired US\$2837, representing 20.9\% of Egypt's total foreign trade flow with all blocs within the African continent, as average of the period (2014-2018). Foreign trade flows between Egypt and both the Community of Sahel-Saharan States and the Moroccan Union followed with values estimated at US\$2720 and 2611.5 million, representing 20\% and 19.3\%, respectively. As for the value of trade between Egypt and the rest of blocs under study (EAC, SADC, SACU, IGAD), it reached some US $\$ 4029.3$ million, representing $29.8 \%$ of the total value of trade between Egypt and African economic blocs, as average of the period (2014-2018).

It is therefore clear that, in terms of relative importance, the COMESA is considered the most important African bloc Egypt exchanges trade with.

Table 1: Relative Importance of Trade Flow between Egypt and Main Economic Blocs in the African Continent as Average of the Period 2014-2018 (in Million US\$)

\begin{tabular}{lcccccc}
\hline Economic Bloc & $\begin{array}{c}\text { Imports } \\
\text { Value }\end{array}$ & $\begin{array}{c}\text { \% } \\
\text { Value }\end{array}$ & $\begin{array}{c}\text { Exports } \\
\text { Va }\end{array}$ & $\begin{array}{c}\text { Trade } \\
\text { Value }\end{array}$ & $\%$ \\
\hline Community of Sahel-Saharan States & 650.2 & 19 & 2069.8 & 20.5 & 2720 & 20.1 \\
Arab Maghreb Union & 668.9 & 19.6 & 1942.6 & 19.2 & 2611.5 & 19.3 \\
COMESA & 669.3 & 19.6 & 2167.6 & 21.5 & 2836.9 & 20.9 \\
EAC & 356.1 & 10.4 & 394.1 & 3.9 & 750.2 & 5.5 \\
SADC & 385.2 & 11.3 & 660.4 & 6.5 & 1045.6 & 7.7 \\
SACU & 96.5 & 2.8 & 667.7 & 6.6 & 764.2 & 5.7 \\
IGAD & 446.9 & 13.0 & 1022.4 & 10.1 & 1469.3 & 10.9 \\
$\begin{array}{l}\text { Other Blocs } \\
\text { Total Value of Intra-Trade Flow between } \\
\text { Blocs inside the African Content }\end{array}$ & 146.9 & 4.3 & 1176.8 & 11.7 & 1323.7 & 9.9 \\
\hline
\end{tabular}

\section{Where,}

Community of Sahel-Saharan States (CEN-SAD): Comprises 29 countries, of which 6 are members of the COMESA, namely Libya, Sudan, Eritrea, Egypt, Kenya and Djibouti;

(EAC): East African Community;

(SADC): Southern African Development Community;

(SACU): Southern African Customs Union;

(IGAD): Intergovernmental Authority on Development;

(UEMOA): West African Economic and Monetary Union.

Source: the Central Agency for Public Mobilization and Statistics, National Information Center, published data.

\subsection{Evolution of Agricultural Trade Flow between Egypt and the COMESA Bloc}

This part focuses on studying and analyzing foreign agricultural trade flow between Egypt and the COMESA Bloc over the period (2001-2018). Data in Table (2) indicate that the value of Egyptian agricultural imports from the COMESA recorded an average of US\$235 million, and ranged between a minimum of US\$37 million and a maximum of US\$360 million. Moreover, the value of agricultural imports from the COMESA account for 5.8\% of Egypt's average agricultural imports from the World over the study period, estimated at US\$4063 million. 
Table 2: Evolution of Agricultural Trade Flow between Egypt and the COMESA over the Period 20012018 (In Million US\$)

\begin{tabular}{|c|c|c|c|c|c|c|}
\hline Indicato & $\begin{array}{l}\text { or Value of Egyptian } \\
\text { Agric. Imports } \\
\text { from the World }\end{array}$ & $\begin{array}{l}\text { Value of Egyptian } \\
\text { Agric. Imports } \\
\text { from the } \\
\text { COMESA }\end{array}$ & $\begin{array}{c}\text { Value of Agric. } \\
\text { Imports from the } \\
\text { COMESA to } \\
\text { Agric. Imports } \\
(\%) \\
\end{array}$ & $\begin{array}{l}\text { Value of Egyptian } \\
\text { Agric. Exports } \\
\text { from the World }\end{array}$ & $\begin{array}{l}\text { Value of Egyptian } \\
\text { Agric. Exports } \\
\text { from the } \\
\text { COMESA }\end{array}$ & $\begin{array}{l}\text { Value of Agric. } \\
\text { Exports from the } \\
\text { COMESA to } \\
\text { Agric. Exports } \\
(\%) \\
\end{array}$ \\
\hline 2001 & 1922 & 159 & 8.3 & 400 & 27 & 6.8 \\
\hline 2002 & 2156 & 226 & 10.5 & 444 & 20 & 4.5 \\
\hline 2003 & 1684 & 124 & 7.4 & 532 & 36 & 6.8 \\
\hline 2004 & 1705 & 65 & 3.8 & 845 & 31 & 3.7 \\
\hline 2005 & 2408 & 53 & 2.2 & 983 & 75 & 7.6 \\
\hline 2006 & 2269 & 37 & 1.6 & 930 & 57 & 6.1 \\
\hline 2007 & 3647 & 57 & 1. 6 & 1193 & 102 & 8.6 \\
\hline 2008 & 4819 & 262 & 5.4 & 2075 & 116 & 5.6 \\
\hline 2009 & 4390 & 271 & 6.2 & 2915 & 187 & 6.4 \\
\hline 2010 & 5632 & 263 & 4. 7 & 3131 & 310 & 9.9 \\
\hline 2011 & 8211 & 371 & 4.5 & 3026 & 127 & 4.2 \\
\hline 2012 & 8806 & 325 & 3.7 & 2684 & 226 & 8.4 \\
\hline 2013 & 5133 & 346 & 6.7 & 2867 & 245 & 8.6 \\
\hline 2014 & 4165 & 388 & 9.3 & 2954 & 212 & 7.2 \\
\hline 2015 & 4100 & 290 & 7.1 & 2852 & 149 & 5.2 \\
\hline 2016 & 3840 & 300 & 7.8 & 2676 & 134 & 5.0 \\
\hline 2017 & 4012 & 329 & 8.2 & 2496 & 155 & 6.2 \\
\hline 2018 & 4235 & 360 & 8.5 & 2981 & 162 & 5.4 \\
\hline $\begin{array}{l}\text { Period's } \\
\text { Average }\end{array}$ & 4063 & 235 & 5.8 & 1999 & 132 & 6.5 \\
\hline
\end{tabular}

Source: The Central Agency for Public Mobilization and Statistics, National Information Center, published data.

In regards to the value of Egyptian agricultural exports to the COMESA over the period (20012018), data in Table (2) indicate that it recorded an average of US\$132 million. It is also clear from the foreign trade coverage ratio that the ratio between the value of exports and that of imports between Egypt and the COMESA recorded an average of 56\%, and ranged between a maximum of $117 \%$.

\subsection{Efficiency of Agricultural Trade between Egypt and the COMESA}

In order to identify the impact of joining the Bloc, the research estimated indicators concerning foreign trade between Egypt and the COMESA over the period (2014-2018), the results of which are presented in Table (3). It can be noticed that the coverage ratio of Egyptian exports to imports from the COMESA countries reached $48.7 \%$, indicating that agricultural exports from Egypt is still incapable of covering her agricultural imports from the COMESA.

Table 3: Indicators of Foreign Trade between Egypt and the COMESA over the Period 2014-2018

\begin{tabular}{lc}
\hline Indicator & $\%$ \\
\hline Export/Import Coverage Ratio & 48.7 \\
Economic Participation & 5.1 \\
Economic Dependency Rate & 1.1 \\
Economic Openness & 1.9 \\
Intensity of Agricultural Trade & 6.3 \\
Intensity of Agricultural Exports & 6.5 \\
Intensity of Agricultural Imports & 2.4 \\
Share of Annual Growth Rate of Intra Agricultural Exports & 10.6 \\
Share of Annual Growth Rate of Intra Agricultural Imports & 4.2 \\
Coefficient of Instability of Agricultural Exports & 7.9 \\
Coefficient of Instability of Agricultural Imports & 38.5 \\
\hline
\end{tabular}

Source: Calculated based on Data Collected from the World Bank Website

Results also revealed that Egypt's economic participation rate reached 5.1\%, indicating that Egypt's participation in agricultural trade to total foreign agricultural trade with the COMESA countries over the study period is low. On the other hand, economic dependency reached $1.1 \%$, which is also low. 
Such result indicates that even after joining the COMESA Bloc, Egypt's economy still depends on external sources to a large extent.

In addition, results revealed a low degree of economic openness between Egypt and the COMESA Bloc, where it reached 1.9\%, as shown in Table (3). Moreover, contribution of agricultural trade between Egypt and the COMESA countries to total Egyptian agricultural trade reached 6.3\%. Results also showed the importance Egyptian agricultural exports to countries of the COMESA represent in total Egyptian agricultural exports to the World, where the estimated rate of intensity of agricultural exports to the COMESA reached $6.5 \%$. On the other hand, intensity of agricultural imports to the COMESA returned a low a rate, estimated at $2.4 \%$, indicating a low relative importance of Egyptian imports from the COMESA during the study period (2014-2018).

The research assessed the stability of agricultural exports and imports between Egypt and the COMESA. Results returned a low value of the estimated coefficient of instability of agricultural exports to the COMESA, where it reached $7.9 \%$, indicating that Egypt's agricultural exports to the COMESA enjoyed a relative degree of stability during the study period. However, the estimated coefficient of instability of agricultural imports from the COMESA reached $38.5 \%$, indicating fluctuations in Egyptian agricultural imports from the COMESA, as shown in Table (3). In regards to the annual growth rate of agricultural exports to the COMESA, it reached $10.6 \%$, while the annual growth rate of agricultural imports from the COMESA reached $4.2 \%$, indicating high rates of growth of agricultural exports to countries of the COMESA in comparison to growth rate of Egyptian agricultural imports from countries of the COMESA during the study period (2014-2018).

\subsection{Structure of Agricultural Trade Flows between Egypt and the COMESA}

To achieve the research objectives, the research further studied and analyzed the structure of agricultural trade flows between Egypt and the COMESA over the period (2012-2018 )based on two pillars; the first focuses on studying the structure of intra-agricultural imports between Egypt and the COMESA, while the other studies the structure of intra-agricultural exports between Egypt and the COMESA Bloc.

\subsection{Structure of Egyptian Agricultural Imports from the COMESA}

Egypt's agricultural imports from the COMESA bloc reached about US\$333.6 million, as clear from data in Table (4). It can be noticed that Egypt's main agricultural imports from the COMESA bloc include the following commodity groups: tea, coffee, oilseeds, chopped tobacco and cotton. Data presented in the table indicate that the value of tea and coffee imports from the COMESA bloc as average of the study period(2012-2018) amounts to US $\$ 277.5$ million, or $83.2 \%$ of the total value of Egyptian agricultural imports from the COMESA bloc.

As for the imports value of oilseeds, chopped tobacco and cotton, it reached some US\$52.4 million, or $15.7 \%$ of the total value of Egyptian imports from the COMESA bloc as average of the study period (2012-2018). Imports from the two commodity groups amounted to IS\$ 25.0, 23.3 and 4.1 million, respectively, representing $7.5 \%, 7.0 \%$ and $1.2 \%$ of the total value of Egyptian agricultural imports from the COMESA bloc, respectively.

Table 4: Structure of Agricultural Trade Flows between Egypt and the COMESA Expressed as Average of the Period 2014-2018

\begin{tabular}{|c|c|c|c|c|c|}
\hline \multicolumn{3}{|c|}{ Agricultural Imports } & \multicolumn{3}{|c|}{ Agricultural Exports } \\
\hline Commodity & $\begin{array}{c}\text { Value in } \\
\text { Million US\$ }\end{array}$ & $\begin{array}{c}\text { Relative } \\
\text { Importance } \\
(\%)\end{array}$ & Commodity & $\begin{array}{c}\text { Value in } \\
\text { Million US\$ }\end{array}$ & $\begin{array}{c}\text { Relative } \\
\text { Importance } \\
(\%)\end{array}$ \\
\hline Tea and Coffee & 277.5 & 83.2 & Vegetables & 45.5 & 27.7 \\
\hline Oilseeds & 25.0 & 7.5 & Fruits & 41.4 & 25.2 \\
\hline Chopped tobacco & 23.3 & 7.0 & Grains & 22.3 & 13.6 \\
\hline Cotton & 4.1 & 1.2 & Flowers and Trees & 18.1 & 11.0 \\
\hline Other & 3.6 & 1.1 & Spices and Medicinal Plants & 10.2 & 6.2 \\
\hline & & & Legume Crops & 8.3 & 5.1 \\
\hline Total & 333.4 & 100 & Other & 18.6 & 11.3 \\
\hline & & & Total & 164.4 & 100 \\
\hline
\end{tabular}

Source: The Central Agency for Public Mobilization and Statistics, National Information Center, published data. 


\subsection{Structure of Egyptian Agricultural Exports to the COMESA}

Egypt's agricultural exports to the COMESA bloc reached US\$164.4 million as average of the period (2012-2018). It can be noticed that Egypt's most important agricultural exports to the COMESA bloc include the following commodity groups: vegetables, fruits, grains, flowers and trees, spices, medicinal and aromatic plants and leguminous crops. Data presented in the Table (4) indicate that the value of Egyptian exports of vegetables to the COMESA bloc is estimated at US\$45.5 million, or 27.8\% of the total value of Egyptian exports to the COMESA bloc, as average of the period (2012-2018). As for the value of Egyptian exports of fruits to the COMESA bloc, data indicate that it reached US $\$ 41.4$ million, or $25.2 \%$ of the total value of Egyptian agricultural exports to the COMESA bloc as an average for the period (2012-2018).

It is also clear from the table that the value of Egyptian exports of grain to COMESA reached US\$20.3 million, or $13.6 \%$ of the total value of Egyptian agricultural exports to COMESA, as an average for the period (2012-2018).

Finally, the value of Egyptian exports of flowers, trees, spices, medicinal and aromatic plants and leguminous crops to the COMESA bloc amounted to US\$18.1, 10.2, 8.3million, respectively, or $6.2 \%$, $5.1 \%$ and $11.3 \%$ of the total value of Egyptian exports to the COMESA bloc, respectively, as averages of the study period.

\section{Results of Estimating the Gravity Model for Agricultural Trade Exchange between Egypt and the COMESA Countries}

The gravity model for agricultural trade between Egypt and the COMESA countries during the period (2000-2018) was estimated, both for agricultural imports and exports. While the total number of COMESA member states is nineteen, the research selected the most important 6 countries in terms of agricultural exports, namely Libya , Sudan, Kenya, Ethiopia, Eritrea and Djibouti, where Egypt's exports to these countries account for $95 \%$ of the volume of Egypt's agricultural exports to the COMESA bloc. As for agricultural imports, 6 countries were also selected, including Libya, Sudan, Zambia, Malawi, Ethiopia and Djibouti, where Egyptian imports from these countries account for $94 \%$ of the total volume of Egyptian agricultural imports from the COMESA bloc, as an average for the period (2000-2018). ). Such figures were estimated using the Basic Gravity Model.

\section{Results of Estimating the Gravity Model for Agricultural Imports \\ I. Results of the Estimated Basic Gravity Model for Agricultural Imports}

Reviewing Table (5), which presents the results of estimating the Basic Gravity Model for agricultural imports, indicates that GDPs for Egypt and the six COMESA countries included in the model, the geographical distance between Egypt and each of the six countries, as well as dummy variables used to reflect the common borders between countries and membership of the Community of Sahel-Saharan States explain about $66 \%$ of the changes in Egypt's agricultural imports from those countries. The value of (F) test, estimated at 29.39, proved that the estimated model is statistically significant.

It is also clear that a direct relationship exists between Egypt's GDP and the volume of Egypt's agricultural imports from the mentioned countries, where 1\% increase in Egypt's GDP leads to increasing Egypt's agricultural imports from the six mentioned countries by $1.6 \%$. As for the inverse relationship between GDPs of the COMESA countries and the volume of Egypt's agricultural imports from those countries, it did not prove statistically significance.

Results also indicate a direct relationship between the geographical distances between Egypt and each of the six countries and Egypt's agricultural imports from those countries, which might be attributed to the fact that most of Egypt's imports from the six countries are imperishable goods that tolerate transportation as, such as tea, coffee, oilseeds, chopped tobacco and cotton.

In regards to the relationship between the dummy variable representing the existence of common borders between Egypt and the COMESA countries on one side, and the volume of Egypt's agricultural imports from those countries on the other side, results demonstrated the existence of a direct relationship, which is consistent with the economic logic, where the existence of common borders between Egypt and the COMESA countries resulted in increasing Egyptian agricultural imports by $3.2 \%$. Moreover, results regarding the dummy variable representing membership of the Community of Sahel-Saharan State indicate an increase in Egypt's agricultural imports from those countries by $2.0 \%$. 


\section{Results of Estimating the Gravity Model for Agricultural Exports}

\section{Results of the Estimated Basic Gravity Model for Agricultural Exports}

Reviewing Table (5), which presents the results of estimating the Basic Gravity Model for agricultural exports, indicates that GDPs for Egypt and the six COMESA countries included in the model, the geographical distance between Egypt and each of the six countries, as well as dummy variables used to reflect the common borders between countries and membership of the Community of Sahel-Saharan States explain around 69\% of the changes in Egypt's agricultural exports to those countries. The value of (F) test, estimated at 39.3, proved the statistical significance of the estimated model.

It is also clear that a direct relationship exists between Egypt's GDP and the volume of Egypt's agricultural exports to the six countries, where 1\% increase in Egypt's GDP leads to increasing Egypt's agricultural exports from the six mentioned countries by $0.05 \%$. The inverse relationship between GDPs of the COMESA countries and the volume of Egypt's agricultural exports to those countries did not prove statistically significance.

Results also indicate an inverse relationship between the geographical distances between Egypt and each of the six countries and Egypt's agricultural exports to those countries, which is consistent with both the economic and statistical logic. This means that $1 \%$ increase in the geographical distances between Egypt and those countries results in reducing Egypt's agricultural exports to those countries by $0.92 \%$.

In regards to the relationship between the dummy variable representing the existence of common borders between Egypt and the COMESA countries on one side, and the volume of Egypt's agricultural exports to those countries on the other side, results revealed the existence of a direct relationship, which is consistent with the economic logic, where the existence of common borders between Egypt and the COMESA countries resulted in increasing Egyptian agricultural exports by $4.95 \%$. In regards to the relationship between the dummy variable representing membership of the Community of Sahel-Saharan State, results revealed that it did not prove statistically significant.

Table 5: Results of Estimating Gravity Models for Egypt's Agricultural Trade with Countries of the COMESA Bloc over the Period 2000-2018.

\begin{tabular}{|c|c|c|}
\hline \multirow{2}{*}{ Variable } & \multicolumn{2}{|c|}{ Imports $\left(\operatorname{LnY} Y_{i j}\right)$} \\
\hline & BGM & BGM \\
\hline Constant & $-14.335^{* *}(-5.469)$ & $-1.764^{* *}(-2.53)$ \\
\hline LnGDPi & $1.631(4.210)^{* *}$ & $0.051(2.321) * *$ \\
\hline LnGDPj & $-0.014(-0.234)$ & $-0.091(-0.728)$ \\
\hline Distance & $8.543(8.997)^{* *}$ & $-0.923)(-2.597)^{* *}$ \\
\hline LnGDPi Per Capita & -- & -- \\
\hline LnGDPj Per Capita & -- & -- \\
\hline Border Dij & $3.22(6.232)^{* *}$ & $4.952(8.046)^{* *}$ \\
\hline Coast,desertDij & $1.951^{* *}(3.603)$ & $0.605(1.879)$ \\
\hline $\mathbf{N}$ & 96 & 96 \\
\hline $\mathbf{R}^{2}$ & 0.66 & 0.69 \\
\hline Ajusted $R^{2}$ & 0.67 & 0.64 \\
\hline F test & ${ }^{* *}(29.397)$ & $(39.329)^{* *}$ \\
\hline
\end{tabular}

Where,

Figures between parentheses below regression coefficients refer to calculated $t$

** Indicates statistical significance at 0.01 level

BGM refers to Basic Gravity Model

Source: The Central Agency for Public Mobilization and Statistics, National Information Center, published data.

\section{Summary}

The Common Market for Eastern and Southern Africa (COMESA) is considered of the most important forms of economic cooperation in the African Continent. Recently, African countries have tended to adopt economic cooperation rather than political conflict. Egypt has joined the bloc on June 29,1998 , and started implementing the principle of reciprocity through applying custom exemptions as of February 17, 1999. The research investigates the problem that the volume of trade exchange between Egypt and the COMESA countries in general, and agricultural trade in particular, is considered 
microcosm and unstable due to being affected by political issues from time to time. It only accounts for $7.2 \%$ of the volume of trade exchange between Egypt and the world. It was found that agricultural trade balance is biased in favor of the COMESA countries. In the light of the described research problem, the main objective the research aimed to achieve is to analyze intra-trade flows between Egypt and countries of the COMESA Bloc, and exploring the ways to achieve full benefit from joining the Bloc. Studying foreign agricultural trade flow between Egypt and the COMESA Bloc over the period (2001-2018) revealed that the value of Egyptian agricultural imports from the COMESA recorded an average of US\$235 million, while the value of Egyptian agricultural exports to the COMESA recorded an average of US $\$ 132$ million. Studying the structure of agricultural trade flows between Egypt and the COMESA over the period (2012-2018) revealed that Egypt's main imports from the COMESA bloc include the commodity groups: tea, coffee, oilseeds, chopped tobacco and cotton. Average value of tea and coffee imports from the COMESA bloc reached US\$277.5 million, or $83.2 \%$ of the total value of Egyptian agricultural imports from the COMESA bloc, estimated at US\$333.6 for the period (2012-2018). As for the imports value of oilseeds, chopped tobacco and cotton, it reached some US\$52.35 million, or $15.69 \%$ of the total value of Egyptian imports from the COMESA bloc as average of the study period (2012-2018). In regards to the structure of agricultural exports to the COMESA bloc, main export commodity groups included vegetables, fruits, grains, flowers and trees, spices, medicinal and aromatic plants and leguminous crops. Average value of Egyptian vegetable exports to the COMESA bloc over the period (2012-2018) reached US\$45.5 million or 27.8\% of the total value of Egyptian exports to the COMESA bloc, estimated at US\$164.4 million. The value of Egyptian exports of fruits to the COMESA bloc reached US\$41.4 million, or $25.2 \%$ of the total value of Egyptian agricultural exports to the COMESA bloc, whereas exports of grain flowers, trees, spices, medicinal and aromatic plants and leguminous crops to the COMESA bloc accounted for $13.6 \%, 6.2 \%, 5.1 \%$ and $11.3 \%$ of the total value of Egyptian exports to the COMESA bloc, respectively. Results of estimating the Basic Gravity Model for Egypt's agricultural imports from the COMESA indicated a direct relationship between Egypt's GDP and the volume of Egypt's agricultural imports from the mentioned countries, where $1 \%$ increase in Egypt's GDP lead to increasing Egypt's agricultural imports from the six mentioned countries by $1.6 \%$. Results also indicated a direct relationship between the geographical distances between Egypt and each of the six countries and Egypt's agricultural imports from those countries, which might be attributed to the fact that most of Egypt's imports from the six countries are imperishable goods that tolerate transportation as, such as tea, coffee, oilseeds, chopped tobacco and cotton. In regards to the relationship between the dummy variable representing the existence of common borders between Egypt and the COMESA countries, result indicated that it has a direct relationship with the volume of Egypt's agricultural imports from those countries, which is consistent with the economic logic, where the existence of common borders between Egypt and the COMESA countries resulted in increasing Egyptian agricultural imports by $3.2 \%$. Moreover, results regarding the dummy variable representing membership of the Community of Sahel-Saharan State indicated an increase in Egypt's agricultural imports from those countries by $2.0 \%$. Results of estimating the Basic Gravity Model for agricultural exports indicated that a direct relationship exists between Egypt's GDP and the volume of Egypt's agricultural exports to the six countries, where 1\% increase in Egypt's GDP leads to increasing Egypt's agricultural exports from the six mentioned countries by $0.05 \%$. As for the relationship between the geographical distances between Egypt and each of the six countries and Egypt's agricultural exports to those countries, results indicated an inverse relationship, which is consistent with both the economic and statistical logic, where a $1 \%$ increase in the geographical distances resulted in reducing Egypt's agricultural exports to those countries by $0.92 \%$. In regards to the relationship between the dummy variable representing the existence of common borders between Egypt and the COMESA countries, results revealed that it has a direct relationship with the volume of Egypt's agricultural exports to six countries, which is consistent with the economic logic, where the existence of common borders between Egypt and the COMESA countries resulted in increasing Egyptian agricultural exports by $4.95 \%$. In regards to the relationship between the dummy variable representing membership of the Community of Sahel-Saharan State, results revealed that it did not prove statistically significant.

\section{Recommendations}

1. Devoting attention to providing appropriate means of transportation, besides developing the currently existing means of transportation between Egypt and each of the COMESA countries so as 
to increase Egyptian agricultural exports to those markets in order to overcome the adverse impact of the geographic distance on the volume of Egyptian agricultural exports to the COMESA markets.

2. Studying quality standards requirements of exports demanded by the COMESA markets thus paying attention to improving the quality of Egyptian exports to those markets, which helps increase agricultural exports to the COMESA countries, especially from commodities in which Egypt enjoys a high comparative and competitive advantage. This is because studies revealed that increases in per capita income in the COMESA countries lead to reducing demand for Egyptian exports, which indicates that Egyptian exports to the COMESA markets lack the required quality standards.

3. Seeking to on open new market windows for Egyptian agricultural exports while maintaining the existing markets, where they are concentrated in a limited number of the COMESA bloc countries.

\section{References}

A study titled "An Analytical Study of Evolutions in Trade Relations between Egypt, the COMESA, blocs and pivotal countries, Trade Agreements Sector, June 2015.

Gehan M. Alafify and Soad A.E. Mousa, 2018. Analytical Study of Investments and Foreign Trade between Egypt and COMESA Countries", Journal of Agricultural Economics and Social Science, Mansoura University, 9(1): 4.

The World Bank, website on the Internet

The Central Agency for Public Mobilization and Statistics, National Information Center, published data. Weld Mohamed Issa Mohamed Mahmoud, 2012. Obstacles to Regional Economic Blocs in Developing Countries: A Case Study of the COMESA Bloc. University of Mostaganem, Algeria, 